\title{
Predicting land-use change and its impact on the groundwater system of the Kleine Nete catchment, Belgium
}

\author{
J. Dams ${ }^{1}$, S. T. Woldeamlak ${ }^{1}$, and O. Batelaan ${ }^{1,2}$ \\ ${ }^{1}$ Dept. of Hydrology and Hydraulic Engineering, Vrije Universiteit Brussel, Pleinlaan 2, 1050 Brussels, Belgium \\ ${ }^{2}$ Dept. Earth and Environmental Sciences, Katholieke Universiteit Leuven, Celestijnenlaan 200E, 3001 Heverlee, Belgium
}

Received: 24 October 2007 - Published in Hydrol. Earth Syst. Sci. Discuss.: 23 November 2007

Revised: 5 December 2008 - Accepted: 5 December 2008 - Published: 15 December 2008

\begin{abstract}
Land-use changes are frequently indicated to be one of the main human-induced factors influencing the groundwater system. For land-use change, groundwater research has mainly focused on the change in water quality thereby neglecting changes in quantity. The objective of this paper is to assess the impact of land-use changes, from 2000 until 2020, on the hydrological balance and in particular on groundwater quantity, as results from a case study in the Kleine Nete basin, Belgium. New is that this study tests a methodology, which couples a land-use change model with a water balance and a steady-state groundwater model. Four future land-use scenarios (A1, A2, B1 and B2) based on the Special Report on Emission Scenarios (SRES) are modelled with the CLUE-S model. Water balance components, groundwater level and baseflow are simulated using the WetSpass model in conjunction with a steady-state MODFLOW groundwater flow model. Results show that the average recharge decreases with $2.9,1.6,1.8$ and $0.8 \%$ for scenario A1, A2, B1 and B2, respectively, over the 20 covered years. The predicted reduction in recharge results in a small decrease of the average groundwater level in the basin, ranging from $2.5 \mathrm{~cm}$ for scenario A1 to $0.9 \mathrm{~cm}$ for scenario $\mathrm{B} 2$, and a reduction of the baseflow with maximum $2.3 \%$ and minimum $0.7 \%$ for scenario $\mathrm{A} 1$ and $\mathrm{B} 2$, respectively. Although these averages appear to indicate small changes in the groundwater system, spatial analysis shows that much larger changes are located near the major cities in the study area. Hence, spatial planning should take better account of effects of land-use change on the groundwater system and define mitigating actions for reducing the negative impacts of land-use change.
\end{abstract}

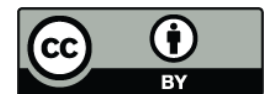

Correspondence to: J. Dams (jefdams@vub.ac.be)

\section{Introduction}

Groundwater is a major source of drinking water across the world and plays a vital role in maintaining the ecological value of many areas (IPCC, 2007; UN/WWAP, 2006). However, the quantity and quality of groundwater are changing due to human activity (Gehrels et al., 2001) jeopardizing the suitability of the groundwater system as a source of drinking water and affecting natural reserves. Assessing the impact on the groundwater system and predicting the magnitude of change in the future is therefore a major scientific challenge (Tong, 2006; Wang et al., 2008). Land-use and land-cover changes are one of the main human induced activities altering the groundwater system (Calder, 1993). Nevertheless, the impact of future land-use changes on the groundwater system has not been investigated extensively. Throughout the entire history of mankind, intense human utilization of land resources has resulted in significant changes of the land-use and land-cover (Bronstert, 2004). Since the era of industrialization and rapid population growth, land-use change phenomena have strongly accelerated in many regions.

Land-use changes are known to impact the hydrology of the catchment area (e.g. Bhaduri et al., 2000; Fohrer et al., 2001; Bronstert et al., 2002; Ott and Uhlenbrook, 2004; Hundecha and Bárdossy, 2004; Tang et al., 2005). The research of the impact of land-use changes on surface hydrology has therefore received considerable attention from both field observations and model simulations.

Experimental research studying paired catchments has shown that a reduction in forest cover causes an increase in water yield, whereas an increase in forest cover causes a decrease in water yield. Coniferous forests consume more water than deciduous hardwoods, brush and grasslands use less water than forests (Bosch and Hewlett, 1982; Brown et al., 2005). Robinson et al. (2003) found that for north-western

Published by Copernicus Publications on behalf of the European Geosciences Union. 


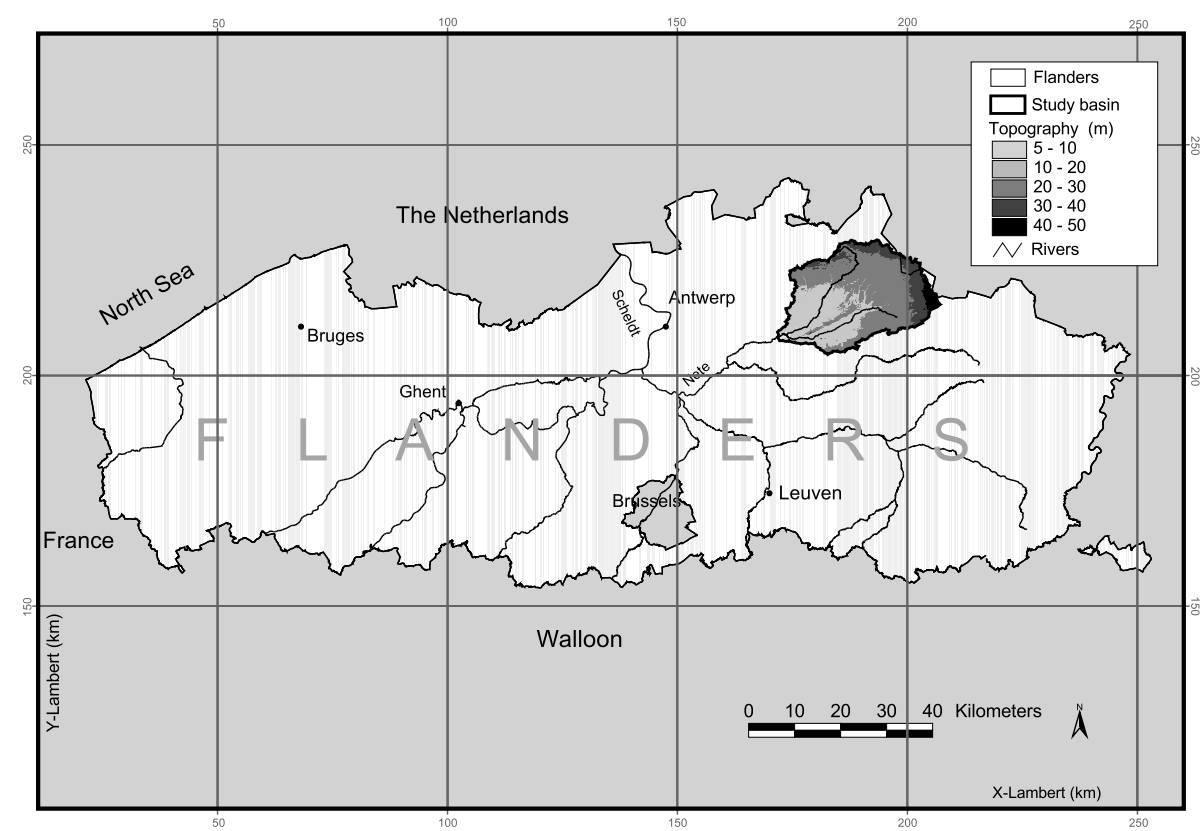

Fig. 1. Location of the study area.

Europe, apart from coniferous forest on poorly drained soils, changes in forest cover at a regional scale will likely have a relatively small effect on peak and low flows. In temperate zones it is almost uniformly observed that deforestation leads to an increase in baseflow (Hornbeck et al., 1993). In urbanized areas direct recharge due to infiltration of precipitation is often reduced, but so is evapotranspiration. On the other hand recharge is often increased by losses from water supply and sewage systems (Vázquez-Suñé et al., 2005).

Apart from those experimental studies a substantial amount of research on the hydrological impact of land-use change is performed using hydrological models. Bahremand et al. (2006), Bultot et al. (1990) among others used a modeling approach to assess the impact of reforestation on the hydrology. Bahremand et al. (2006) concluded that 50\% increase of forest areas decreased the peak discharges by $12 \%$. Such hypothetical scenario approaches allow assessing the impact of some fundamental changes in the land-use, though they do not allow assessing the future land-use. Land-use change models, however, have been developed to predict future land-use conditions (Verburg et al., 1999). Niehoff et al. (2002), Tang et al. (2005), Tong and Liu (2006), Lin et al. (2007) and McColl and Aggett (2007) couple landuse change and hydrological models. Niehoff et al. (2002) uses the land-use change modeling kit (LUCK) in conjunction with a modified version of the physically based hydrological model WaSiM-ETH for flood prediction. Tang et al. (2005) applies the Land Transformation Model (LTM) in combination with the Long-Term Hydrologic Impact Assessment (LTHIA) model (Bhaduri et al., 2000). Lin et al. (2007) tests the generalized watershed loading functions model us- ing predicted land-use from the CLUE-S model (Verburg et al., 1999; Verburg et al., 2004). McColl and Aggett (2007) test the hydrological model HEC-HMS together with the land-use forecasting model What if?. In these studies landuse change models have shown to provide useful information that allows assessing the impact of future land-use on the hydrology.

However, due to computational constraints, data availability and model complexity above mentioned hydrological models simulate the groundwater system in a simplified way and hence do not provide information on the spatial distributed changes of groundwater levels. The effect of some simplified land-use change scenarios on the groundwater system at mesoscale have been investigated by Klöcking and Haberlandt (2002), Batelaan et al. (2003) and Batelaan and De Smedt (2007). However, so far the use of models for land-use change in hydrological research has been limited to surface-runoff and flood prediction. With the recently approved EU Groundwater Directive a legal framework is established in which monitoring and predicting human induced changes of the groundwater resources requires a more extensive scientific support (EU, 2006).

The objective of this paper is to assess the impact of future land-use on the groundwater system quantitatively and in a spatially distributed manner. A methodology is developed in which a stochastic land-use change model is coupled with a calibrated groundwater flow model. This coupling is new and essential for evaluating the spatially distributed effects of land-use changes on groundwater levels as is e.g. required for the protection of groundwater dependent terrestrial ecosystems. 
The Nete basin, situated in Belgium, was chosen as a study area. Due to the sandy soils and low slopes a large fraction of the effective rainfall in the basin is percolating to the groundwater. The groundwater in the basin is extensively used for drinking water production, while important groundwater dependent wetlands are present. In the past decades strong urbanization processes have significantly changed land-use and are expected to continue, posing negative impacts on groundwater resources.

\section{Study area}

The study area is located in Belgium about $60 \mathrm{~km}$ north-east of Brussels (Fig. 1). It comprises $581 \mathrm{~km}^{2}$ and covers a major part of the Kleine Nete basin. Geologically, it belongs to the Campine basin, a subsidence area north of the Massive of Brabant (Wouters and Vandenberghe, 1994). From the Late Cretaceous until the end of the Tertiary, the basin went through a subsidence period with deposits of marine sediments. During the early Oligocene, the Clay of Boom was deposited; this heavy clay layer is considered to be an impervious base of the aquifer system. In the Miocene period, the Formation of Berchem and Diest were deposited in a marine environment. During the Pliocene, the study area was dominated by a shallow marine environment, resulting in the sand deposits of Kattendijk and Kasterlee. During the Quaternary, the sea level decreased and sand sediments were deposited by the River Rhine. In the north of the study area, these sands were covered by the Complex of the Campine, a complex of fine sand with clay layers. During the late Pleistocene, the study area was covered by an eolian sand and loess layer of about two meters thick. Finally, during the Holocene, the existing river valley was filled with fluvial sediments with an average thickness of one meter.

The basin has a gradually decreasing slope from the Campine plateau, where the Kleine Nete has its origin, situated north-east of the study area to the mouth of the Nete River in the south-west (Fig. 1). The elevation above sea level ranges from 3 to $48 \mathrm{~m}$, the average elevation is about $24 \mathrm{~m}$, the average slope $0.4 \%$. Interfluves are slightly elevated, the valleys broad and swampy (Wouters and Vandenberghe, 1994). The average precipitation in the area is about $840 \mathrm{~mm} / \mathrm{y}$. The dominant soil texture is sand, though in the valleys some loamy sand, sandy loam and sandy clay is present. In 2000, the land-use of the study area consisted of $38 \%$ agriculture, $19 \%$ meadow, $16 \%$ coniferous forest, $11 \%$ urban, $7 \%$ deciduous forest, $4 \%$ mixed forest, $2 \%$ open water, $1 \%$ heather and $2 \%$ other (OC GIS-Vlaanderen, 2001).

\section{Methodology}

\subsection{Overview}

The methodology consists of three parts. In the first part, the near future land-use change in the study area is modelled. Yearly land-use maps have been created starting from the original land-use map (2000) until 2020. Next, the future land-use maps are used in the WetSpass (Batelaan and De Smedt, 2007) model to calculate the yearly recharge in the catchment. Finally, the recharge is used in a steadystate MODFLOW model to determine the groundwater levels and fluxes. The grid resolution is 50 by $50 \mathrm{~m}$, which is mainly based on the arguments that with this resolution still the whole catchment can be modelled and reasonable homogeneous land-use classes can be distinguished. Furthermore, many of the available data layers do not allow, from information content point of view, a finer resolution than $50 \mathrm{~m}$.

\subsection{Modelling land-use change}

The land-use change model, Conversion of Land-Use and its Effects at Small regional extent (CLUE-S) (Verburg, 1999), is used to simulate future land-use change. The CLUE-S model dynamically allocates land-use changes based on a combination of empirical and spatial analyses (Verburg et al., 1999). This model has been selected based on the criteria: flexibility on the input data (driving forces); the possibility of linking the output to the WetSpass model; and free access to the model (US EPA, 2000).

The CLUE-S modelling procedure consists of two parts; a non-spatial analysis part with a land-use demand module and a spatial analysis part with a land-use allocation module. The land-use demand data (2000-2020) of the study region needed for the non-spatial analysis is obtained using the present land-use in combination with the European trend calculated in the EURURALIS project (Klijn et al., 2005). The EURURALIS project is a European project whose aim is to guide European policy makers in taking decisions for the future of agriculture in Europe. In EURURALIS the land-use demand for different land-use classes is calculated for the whole of Europe using a combination of the LEITAP model, an adapted version of the Global Trade Analysis Project (GTAP), and the Integrated Model to Assess the Global Environment (IMAGE) (Klijn et al., 2005).

For the land-use change allocation procedure four inputs are required: spatial policies and restrictions, land-use type specific conversion settings, location characteristics and future land-use requirements (Fig. 2).

In the input section "spatial policy and restrictions" of the CLUE-S model, areas that are protected for nature conservation can be excluded from certain types of land-use change. For this study, forest, heather and meadow land-use types 


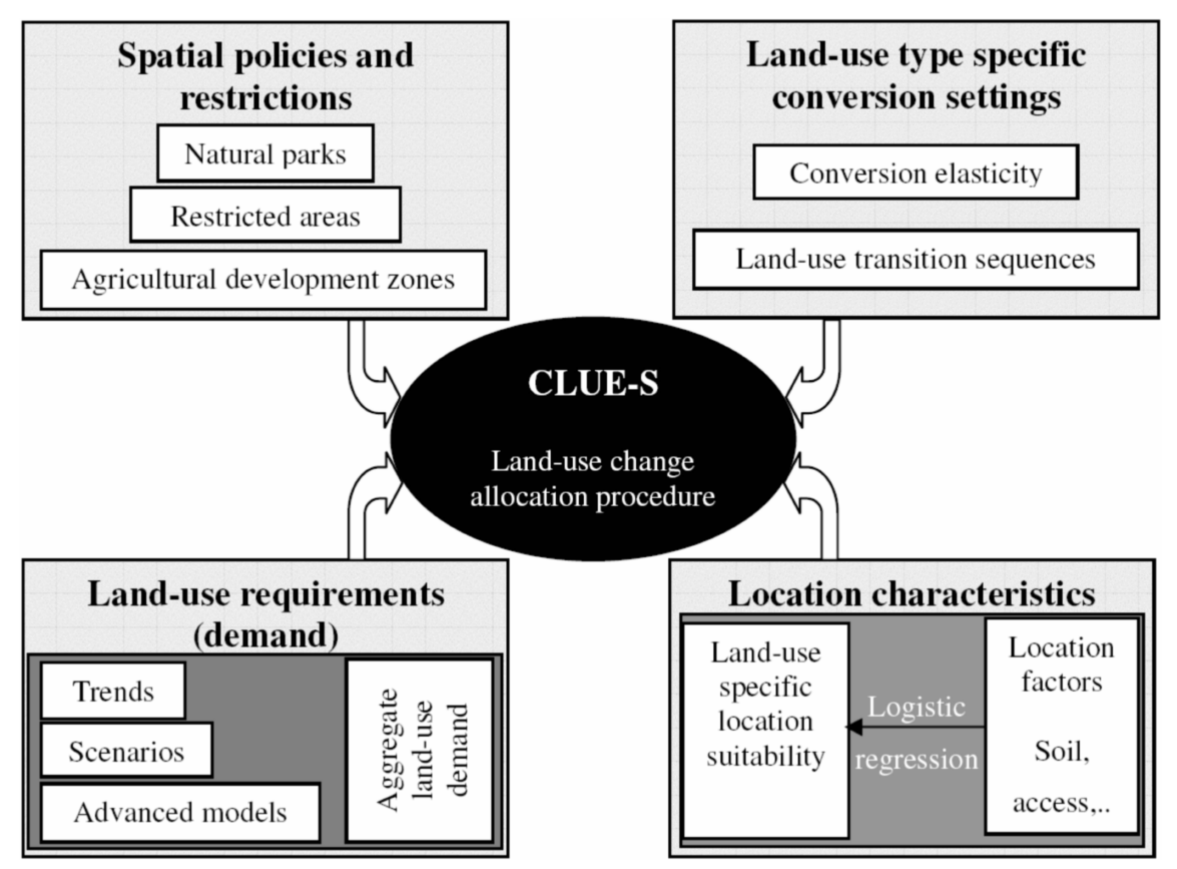

Fig. 2. Overview of CLUE-S input (Verburg et al., 2004).

are not allowed to change to urban, industrial or agricultural land-use types if they are situated in areas protected for nature conservation.

The input section land-use type specific conversion settings characterize the reversibility of a certain land-use change. Conversion settings are based on data described in Verburg et al. (2004).

The driving forces behind the allocation of land-use changes used in this study are soil texture, topography, slope, groundwater depth, distances to major cities and distance to major roads and cannels. To calculate the location characteristics for the different pixels a forward stepwise logistic regression is performed for each land-use type, using present land-use as dependent variable and the driving forces as independent variables. The coefficients obtained from the logistic regression are used in the CLUE-S model to calculate the probability maps for all land-use types.

Finally, land-use requirements, calculated in the nonspatial analysis part, serve as the last input for the allocation procedure of the CLUE-S model. The change in land-use demand is assumed to be linear over the modelled 20 years.

The allocation procedure of the CLUE-S model is shown in Fig. 3. The first step is the determination of the grid cells that are allowed to change using the spatial policies and conversion settings. In the next step, all grid cells are populated with a probability for each land-use type. This probability is obtained by taking the summation of the suitability of each grid cell for a certain land-use type (based on the logistic regression), the conversion elasticity for that land-use type and an iteration variable indicating the relative competitive strength of the land-use type. In the third step, a preliminary land-use change allocation is made using the same value for the iteration variable for all land-use types. Lastly, the total allocated area for each land-use type from the previous step is compared to the land-use requirements (demand). If the allocated area is smaller than the demand, the iteration value for that land-use is increased. If the allocated area is greater than the demand the iteration value is decreased. Steps two to four are repeated until the demand is equal to the area allocated.

\subsection{Recharge and groundwater modelling}

Groundwater recharge, actual evapotranspiration and surface runoff is simulated with the distributed Water and Energy Transfer between Soil, Plants and Atmosphere under quasi-Steady State model (WetSpass) (Batelaan and De Smedt, 2007). The model takes into account distributed soil, land-use, slope, groundwater depth and hydro-climatological maps with associated parameter tables.

Groundwater recharge is simulated in WetSpass as the residual term of the water balance:

$R=P-S-E T-E-I$

where $R$ is groundwater recharge [ $\left[\mathrm{LT}^{-1}\right], P$ is the average seasonal precipitation $\left[\mathrm{LT}^{-1}\right], S$ is runoff over land surface $\left[\mathrm{LT}^{-1}\right], E T$ is the actual evapotranspiration $\left[\mathrm{LT}^{-1}\right], E$ is evaporation from the bare soil $\left[\mathrm{LT}^{-1}\right]$ and $I$ is the interception by vegetation $\left[\mathrm{LT}^{-1}\right]$. 


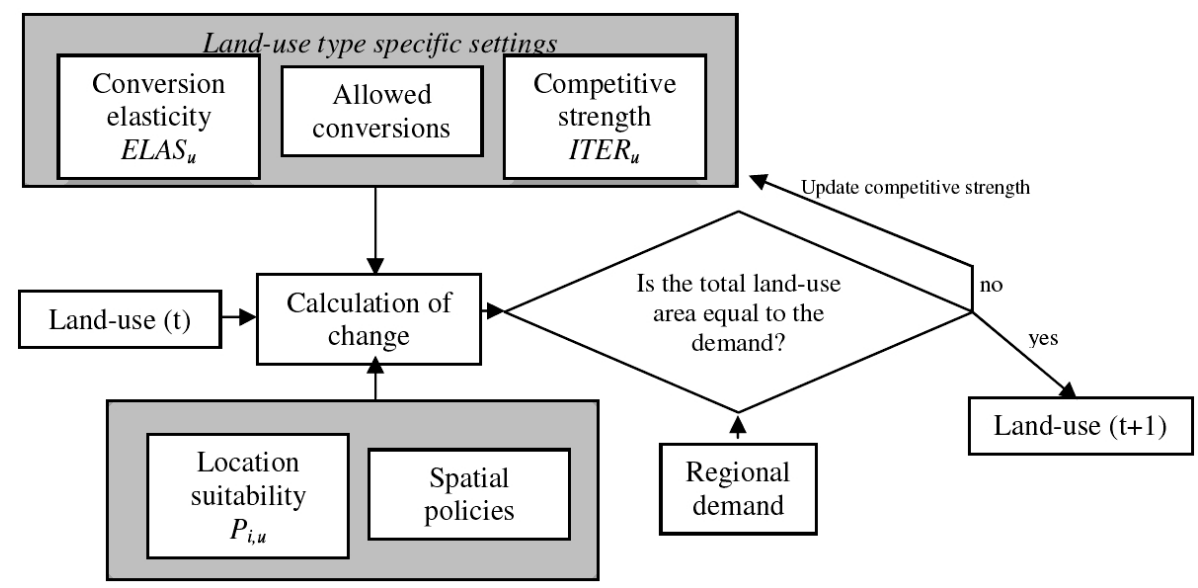

Fig. 3. Allocation procedure of the CLUE-S model (Verburg et al., 2004).

The WetSpass model operates in a spatially distributed manner, with the same resolution as the groundwater model. The distributed approach is essential as the recharge generation processes are highly variable in space.

Finally, the groundwater system is modelled by applying the USGS modular three-dimensional finite difference groundwater model (MODFLOW) (Harbaugh and McDonald, 2000). Because it is the aim to assess the long term effect of land-use change on the groundwater levels and fluxes, steady state MODFLOW models for each year from 2000 until 2020 are developed. Each steady state represents the equilibrium condition assuming the recharge derived from the WetSpass model, incorporating the future land-use simulated for that particular year.

The groundwater model developed for this study is nested in the Flemish Groundwater Model of the Nete basin (Meyus et al., 2004; Verbeiren et al., 2006; Woldeamlak et al., 2007). The conceptual model schematizes the Quaternary and Tertiary sediments in two layers; these sediments are underlain by the Boom clay aquitard. The top layer of the model combines Quaternary and Tertiary layers, except for the Miocene aquifer system, which represents the lower layer. The outer boundaries of the model are set to no-flow conditions, as they coincide with groundwater divides (Verbeiren et al., 2006). The calibrated hydraulic conductivity ranges between 0.1 to $20.5 \mathrm{~m} / \mathrm{d}$ for the top layer, and $6.1 \mathrm{~m} / \mathrm{d}$ for the bottom layer.

The different yearly recharge maps simulated with WetSpass incorporate the modelled future land-use maps and parameterize the RECHARGE package of MODFLOW. For each simulated year between 2000 and 2020, MODFLOW generates groundwater head, budget and flow direction maps for the two layers.

\subsection{Uncertainty assessment methods}

In order to analyse changes in the groundwater system, landuse prediction, water balance and groundwater models are used. To capture the essential processes, these models inevitably have to simplify the complex systems they present. All these models have a degree of uncertainty resulting from their input data, model structure and model parameterization (Walker et al., 2003). The methodology presented in this paper aims to reduce the uncertainty concerning the spatial allocation of predicted land-use changes by using a land-use change model instead of relying on the expert knowledge of a modeller.

Related to the land-use change modelling, two different uncertainties can be distinguished: uncertainty related to the quantity and type of land-use change that is expected and uncertainty related to the allocation of the land-use change.

- Regarding the prediction of the amount and type of land-use change between 2000 and 2020, this study uses the outcomes of the EURURALIS project (Klijn et al., 2005). To incorporate the uncertainty of the future landuse demand an approach, based on the SERS scenarios, is used.

- The CLUE-S model decreases the uncertainty of future land-use allocation by using a stepwise logistic regression methodology, which links land-use types with relevant driving forces of the land-use allocation. The predictive capacity of the model can be evaluated as a function of the percentage of correct classified pixels. A perfect classification for a certain land-use type means that its pixels had the highest probabilities for the landuse, which was used as the dependent variable for the logistic regression. The classification depends on the threshold or cut-off, which is set to classify the land-use type specific probability map. The relative operating characteristic (ROC) evaluates the goodness of fit of the regression models (Lin et al., 2007) by calculating the area under the curve, which plots the proportion of pixels correctly classified as the examined land-use versus 
Table 1. Land-use change in the study area from 2000 until 2020 for four SRES development scenarios A2, A2, B1 and B2.

\begin{tabular}{lcccc}
\hline & \multicolumn{4}{c}{ Land-use change (\%) } \\
& Urban & Agriculture & Forest & Meadow \\
\hline Scenario A1 & +58 & -18 & +2 & -6 \\
Scenario A2 & +32 & -8 & -5 & +1 \\
Scenario B1 & +34 & -17 & +8 & +0 \\
Scenario B2 & +14 & -13 & +10 & +3 \\
\hline
\end{tabular}

pixels falsely classified as that land-use, for an infinite number of these cut-off values (Overmars and Verburg, 2005). ROC values vary from 0.5 (completely random) to 1 (perfect discrimination).

Besides the fact that the logistic regression in the CLUE$\mathrm{S}$ model is unable to capture all land-use allocation properties, also parameter uncertainties cause variations on the simulated groundwater levels. The Monte Carlo method is applied to assess the impact of parameter uncertainty of the CLUE-S model for SRES scenario A1. The Monte Carlo method requires repeated random sampling of CLUE-S input parameters, within their acceptable boundaries, to compute corresponding future land-use, recharge and groundwater head maps. Finally, the standard deviation of the groundwater level is calculated for each pixel. Assuming a normal distribution, the standard deviation is multiplied by 1.96 to obtain the $95 \%$ confidence bounds on the simulated groundwater levels.

The WetSpass model uses a mixture of physical and empirical relationships to calculate the groundwater recharge. Uncertainty in the recharge estimation, along with the parameterization procedures are evaluated by Batelaan and De Smedt (2007). Here it is assumed that parameters related to the land-use type stay constant in time, which means only changes in land-use classes are considered. A simple sensitivity analysis of the WetSpass model toward landuse change was tested by hypothetically changing the whole basin into each land-use type.

In this paper, the calibration of the WetSpass and MODFLOW models was performed simultaneously using average groundwater level observations from 151 piezometers. Obtained groundwater heads in MODFLOW are iteratively used in WetSpass to improve the recharge estimation. Apart from the calibration based on measured piezometric heads, an additional calibration of the baseflow was performed using a numerical filtering technique with the WETSPRO tool (Willems, 2003).

\section{Results and discussion}

\subsection{Land-use modelling}

Based on the most recent land-use map of the study area (2000) (Fig. 4a), future European land-use demands calculated in the EURURALIS project (Klijn et al., 2005), and incorporating the four scenarios, the future land-use changes for the study basin have been determined. Results are presented in Table 1. All scenarios predict an increase in urban area; the increase is maximum in scenario A1 and minimum in scenario B2. In addition, all scenarios predict a decrease in agricultural land-use; the maximum change is predicted for scenario A1, and the minimum for scenario A2. Forest and meadow areas increase, except for scenario A2 and A1, respectively.

Figure 4b-e shows the with CLUE-S simulated land-use maps for the year 2020 for scenarios A1, A2, B1 and B2. It is observed that the increase in urban area is mainly situated close to existing city centres. The results also show that the increase in forest area predicted in scenario B1 and B2 is mainly situated in the eastern part of the study area.

\subsection{Present water balance}

The minimum, maximum, average and standard deviation values of the precipitation, recharge, evapotranspiration and surface runoff fluxes are given in Table 2 . The yearly fluxes are a summation of the summer and winter results.

Table 2 shows that the yearly simulated spatial surface runoff varies between 0 and $660 \mathrm{~mm}$. Comparing the surface runoff map from WetSpass with the land-use map, it becomes clear that land-use has a major impact on the surface runoff. Most of the pixels in the basin have a surface runoff value between 0 and $20 \mathrm{~mm} / \mathrm{y}$. Build up and industry typically have surface runoff between 160 and $250 \mathrm{~mm} / \mathrm{y}$; rivers and lakes between 315 and $570 \mathrm{~mm} / \mathrm{y}$; and the highest surface runoff, between 570 and $660 \mathrm{~mm} / \mathrm{y}$, is observed in some pixels with city centre build up or in some groundwater discharge areas.

Evapotranspiration is the largest component of the water balance. WetSpass estimates the evapotranspiration in the basin as 55\% of the total precipitation. Most evapotranspiration in the basin occurs during summer $(62 \%)$ when the average temperature is higher than in winter (14.1 compared to $5.0^{\circ} \mathrm{C}$ ). In relation to land-use, the highest values for evapotranspiration are found for open waters, followed by (wet) meadow and forest areas. Lower values for evapotranspiration are observed in residential and industrial areas. Agricultural areas generally have an evapotranspiration situated midway between meadow and residential values. The evapotranspiration of vegetation on loamy sand appears generally higher than on sandy soil.

The average yearly recharge is estimated as $292 \mathrm{~mm} / \mathrm{y}$. From this yearly recharge, only $10 \mathrm{~mm}$ occurs during summer; all remaining recharge occurs during winter time. 

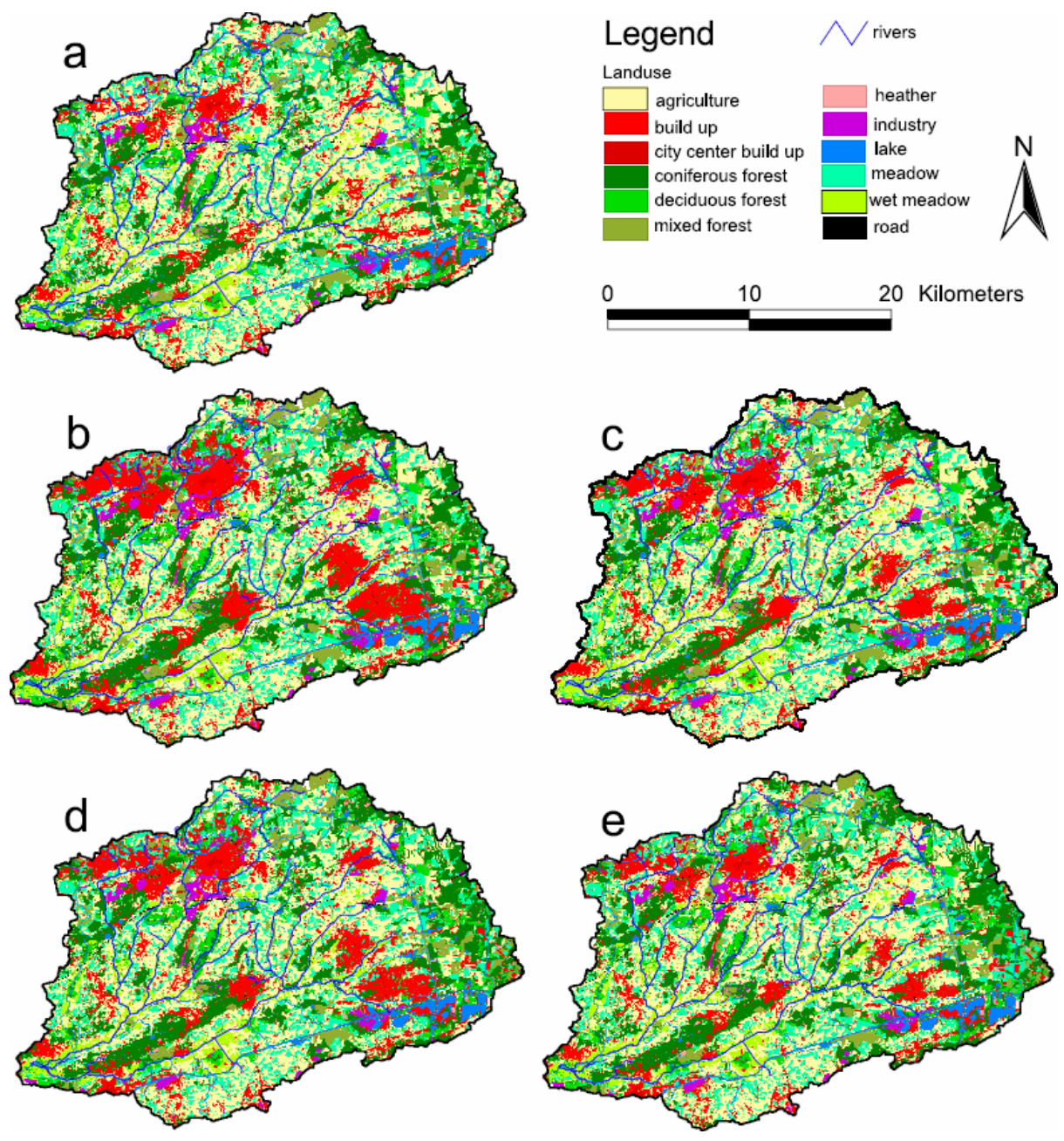

Fig. 4. Land-use maps for the year 2000 (a) and for the year 2020 assuming SRES scenario A1 in (b), A2 in (c), B1 in (d) and B2 in (e).

During summer, negative recharge values are observed because the groundwater discharge towards the land surface in valley areas is counted as negative recharge. Hence, in these valleys vegetation is able to maintain a higher evapotranspiration by pumping up groundwater. Groundwater discharge areas cover about $10 \%$ of the basin and have an average groundwater discharge of $314 \mathrm{~mm} / \mathrm{y}$. Large parts of the groundwater discharge areas correspond to depressions and valleys; at these locations average rates of $4 \mathrm{~mm} / \mathrm{d}$ are simulated, while rates of about $25 \mathrm{~mm} / \mathrm{d}$ are restricted to the river networks. When groundwater discharge is excluded, the areal average recharge is $312 \mathrm{~mm} / \mathrm{y}$, or about $37 \%$ of the annual precipitation.

The spatially distributed groundwater recharge during the year 2000 is shown in Fig. 5. Areas where no recharge occurs are shown in light blue and coincide with open waters. The dark blue color indicates locations of groundwater discharge, which are observed in river valleys and at the edge of the Campine plateau in the east of the basin. Recharge occurs in
$87 \%$ of the basin. In the upper part of the basin, where dark orange colors appear in Fig. 5, recharge is higher than in the lower part of the basin.

Figure 6 compares the areal coverage of the different landuse classes for the simulated recharge conditions for the year 2000. Groundwater discharge occurs primarily in agricultural, forest or meadow areas. The lowest recharge rates are found in the urban centres where impervious land-covers prevent water from infiltrating. Due to the relatively high fraction of gardens and parks in urban areas of this study area, the recharge rate in these urban zones is reasonably high $(100-350 \mathrm{~mm} / \mathrm{y})$. Areas with a yearly recharge higher than $350 \mathrm{~mm}$ are mainly classified as forest, meadow or agriculture. In general, mixed and deciduous forests have a higher yearly recharge than coniferous forest.

\subsection{Impact of future land-use changes on the water balance}

The summer, winter and yearly water balances are simulated with WetSpass for the four future land-use scenarios. For 
Table 2. Yearly, summer and winter water balance components for the Kleine Nete Basin for the year 2000.

\begin{tabular}{|c|c|c|c|c|}
\hline \multicolumn{5}{|c|}{ Yearly } \\
\hline & $\begin{array}{l}\text { Average } \\
(\mathrm{mm})\end{array}$ & $\begin{array}{l}\text { Minimum } \\
(\mathrm{mm})\end{array}$ & $\begin{array}{l}\text { Maximum } \\
(\mathrm{mm})\end{array}$ & $\begin{array}{l}\text { Standard deviation } \\
(\mathrm{mm})\end{array}$ \\
\hline Precipitation & 839 & 798 & 887 & 26 \\
\hline Surface runoff & 93 & 1 & 656 & 168 \\
\hline Actual evapotranspiration & 462 & 260 & 672 & 68 \\
\hline Recharge & 292 & -342 & 476 & 186 \\
\hline \multicolumn{5}{|c|}{ Summer } \\
\hline & $\begin{array}{l}\text { Average } \\
(\mathrm{mm})\end{array}$ & $\begin{array}{l}\text { Minimum } \\
\quad(\mathrm{mm})\end{array}$ & $\begin{array}{l}\text { Maximum } \\
\quad(\mathrm{mm})\end{array}$ & $\begin{array}{l}\text { Standard deviation } \\
(\mathrm{mm})\end{array}$ \\
\hline Precipitation & 384 & 365 & 405 & 12 \\
\hline Surface runoff & 37 & 0 & 290 & 70 \\
\hline Actual evapotranspiration & 345 & 144 & 555 & 66 \\
\hline Recharge & 10 & -360 & 116 & 88 \\
\hline \multicolumn{5}{|c|}{ Winter } \\
\hline & $\begin{array}{l}\text { Average } \\
(\mathrm{mm})\end{array}$ & $\begin{array}{l}\text { Minimum } \\
\quad(\mathrm{mm})\end{array}$ & $\begin{array}{l}\text { Maximum } \\
(\mathrm{mm})\end{array}$ & $\begin{array}{l}\text { Standard deviation } \\
(\mathrm{mm})\end{array}$ \\
\hline Precipitation & 455 & 433 & 481 & 14 \\
\hline Surface runoff & 56 & 0 & 382 & 111 \\
\hline Actual evapotranspiration & 117 & 98 & 143 & 9 \\
\hline Recharge & 283 & -29 & 379 & 113 \\
\hline
\end{tabular}

these scenarios the average change in percentage over the period 2000 to 2020 in runoff, evapotranspiration and recharge fluxes are shown in Fig. 7a-c.

For all scenarios, an increase of yearly surface runoff is observed. Scenario A1 has the largest impact on the yearly surface runoff with an increase of $14 \%$, while scenario B2 has the smallest increase (2.8\%). The surface runoff in scenario $\mathrm{A} 2$ and B1 both increase approximately $8 \%$. In all scenarios, the increase in surface runoff is slightly higher in summer than in winter. A small decrease of the average evapotranspiration is simulated for all scenarios.

The impact of the land-use changes on the recharge is the focus of this study. The predicted decrease of the average recharge is with $2.9 \%$ highest for scenario $\mathrm{A} 1$, while scenarios A2, B1 and B2 have an average decrease of 1.6, 1.8 and $0.8 \%$, respectively. Comparing Fig. $7 \mathrm{~b}$ and $\mathrm{c}$ shows that recharge decreases more during the summer than during winter.

The difference in groundwater recharge due to land-use change between 2000 (Fig. 5) and 2020 for the four scenarios is shown in Fig. 8a-d. The surface coverage where recharge reduces is largest in Scenario A1; most of these zones are situated near urban centers (Fig. 8a). At few locations in the basin recharge increases; within the vicinity of the urban centers these are mostly locations where recharge increases due to reduction of groundwater discharge conditions, at the outlet of the basin the increase is primarily caused by meadows or agricultural fields that are converted to wet meadows. Compared to scenario A1, scenario A2 shows that the surface area where recharge has decreased is considerably smaller (Fig. 8b). In scenario B1, the coverage of the locations where recharge reduces is comparable with scenario A2. However, due to the predicted increase in deciduous forest, more zones with an increase in recharge are simulated for scenario B1, in comparison with scenario A2. Finally, scenario B2 shows the smallest area with a decrease in recharge due to the relatively low increase in urbanization. On the other hand, this scenario shows the largest area with an increase in recharge as a result of afforestation of agricultural fields.

\subsection{Impact of future land-use changes on the groundwater system}

The results of the MODFLOW models show a decrease of the average groundwater level for all four scenarios (Fig. 9). The average groundwater level decrease in the entire basin due to the predicted land-use change over 20 years is 2.5, 1.6, 1.7 and $0.9 \mathrm{~cm}$ for scenario A1, A2, B1 and B2, respectively. Figure 9 clearly indicates that these decreases are almost linear in time as land-use changes are assumed linear in time.

Figure 10a-d shows the spatially distributed effect of the predicted land-use change (2000-2020) on the groundwater level in the basin for all four scenarios. From these figures it 


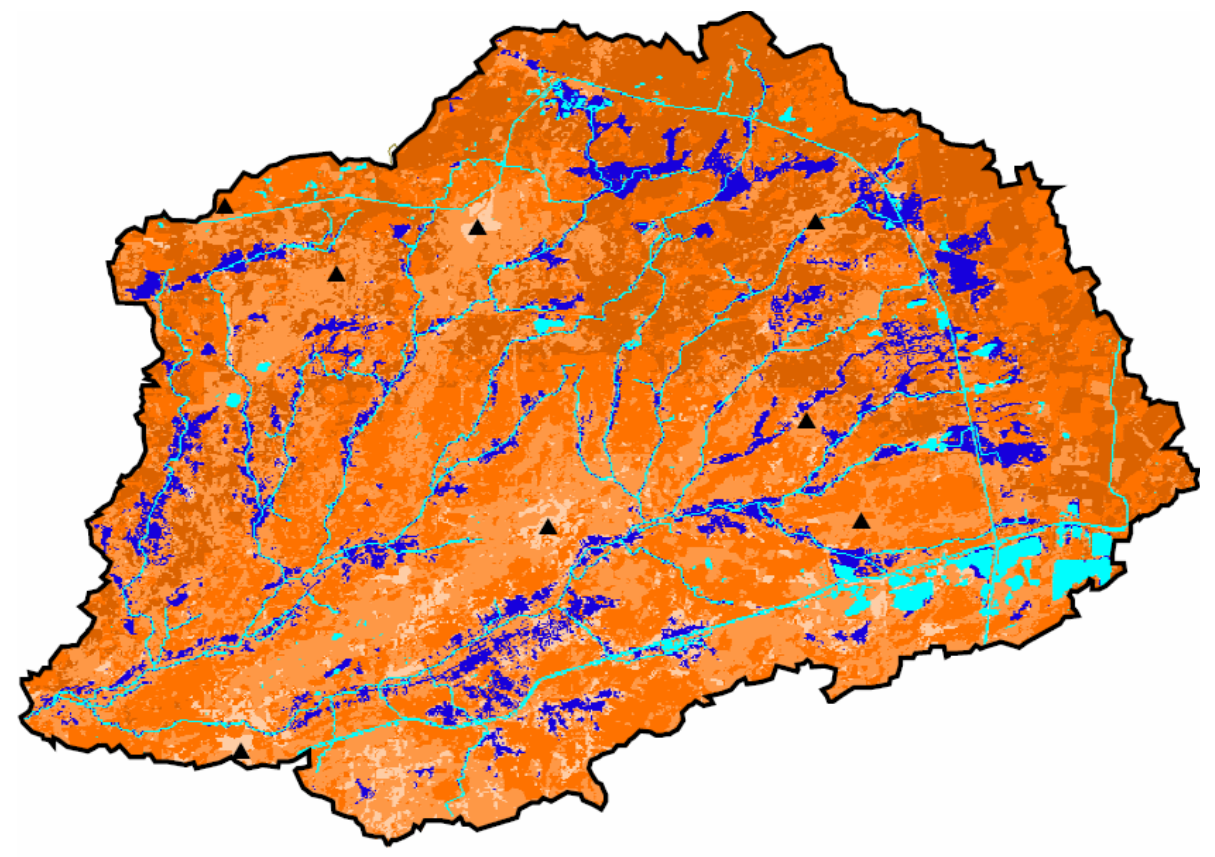

Legend

Groundwater recharge for the year $2000(\mathrm{~mm} / \mathrm{y})$
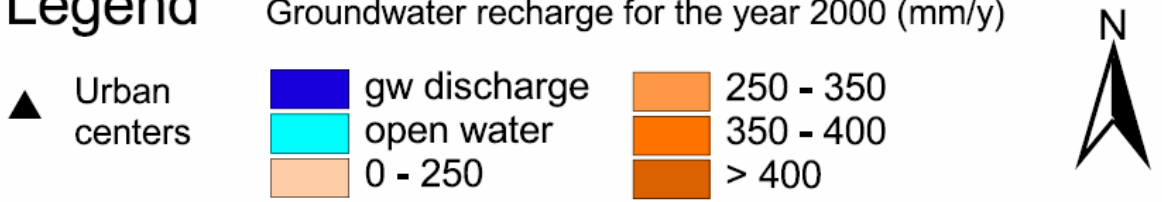

0

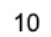

20 Kilometers

Fig. 5. Spatially distributed groundwater recharge during the year 2000 .

is concluded that in the neighbourhood of the villages, where the urbanization rate is high, the groundwater level decrease is also highest. Scenario A1 (Fig. 10a) results in the largest average groundwater level decrease and the largest area with a decrease of more than $10 \mathrm{~cm}$. The maximum decrease in groundwater level is $0.45 \mathrm{~m}$ and is simulated in scenario A1, near the village of Beerse. The outcome of scenarios A2 and B1 are similar; both predict a groundwater level decrease with more than $10 \mathrm{~cm}$ in the neighbourhood of Beerse and Kasterlee. Scenario B2 has the most moderate groundwater level decrease, with only close to Beerse a decrease of more than $10 \mathrm{~cm}$. In all scenarios the largest part of the basin shows a decrease in groundwater level of less than $5 \mathrm{~cm}$, which can be regarded as a level indicative for change.

Figure 11 presents for scenario A1 the regions in which a groundwater level decline of more than $5 \mathrm{~cm}$ is predicted for zones urbanized during the 20 simulated years. The figure clearly indicates most new urban areas as well as the regions with the highest groundwater level decrease are situated within a contour of $3 \mathrm{~km}$ from the largest cities or village centres. From Fig. 10a and 11 it can also be concluded that the sensitivity from the groundwater system toward urban- ization is not equal throughout the basin. The urbanization rate in the north-west of the basin, near Turnhout, Beerse and Vosselaar is similar with the urbanization rate in the east of the basin, near Retie and Dessel (Fig. 11). However, the groundwater level decline in the north-east is much more profound than the decline in the west of the basin. Clearly, the groundwater system in the north-east is more sensitive to urbanization because the changes take place in the upper part of the groundwater system.

The groundwater balance for the four scenarios is presented in Table 3, the given baseflow is calculated as the sum of the drains and river leakage.

The average baseflow in 2000 is simulated as $314 \mathrm{~mm} / \mathrm{y}$ and consists of $103 \mathrm{~mm}$ (33\%) diffuse groundwater discharge in small rivulets (simulated by the drains) and $211 \mathrm{~mm}(67 \%)$ of groundwater discharge into the river system. The groundwater discharge is almost constant for all the scenarios and represents the groundwater evapotranspiration in the shallow groundwater zones. The amount of drainage decreases for all scenarios with a maximum decrease for scenario A1 $(2.4 \%)$ and a minimum decrease for scenario B2 $(0.8 \%)$. Similarly, the groundwater discharge to the rivers decreases for 


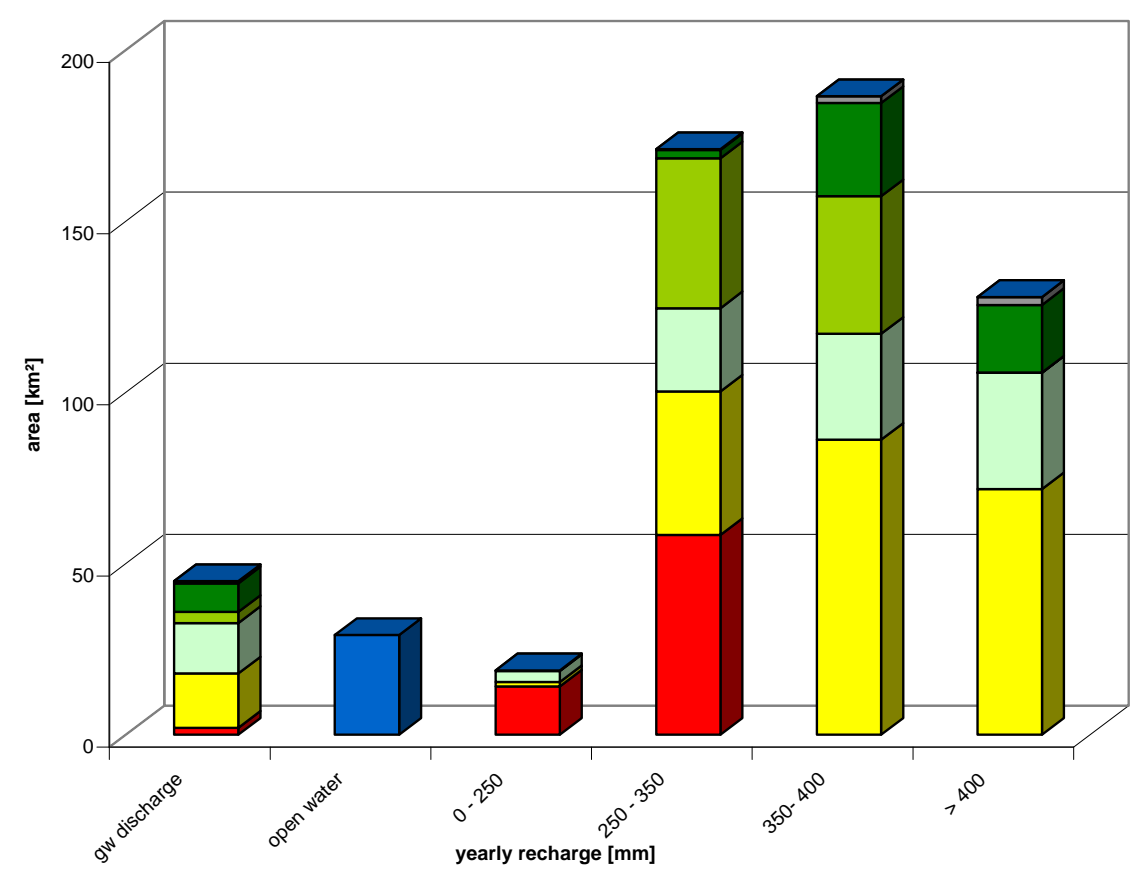

\begin{tabular}{|ll|}
\hline$\square$ urban & $\square$ agriculture \\
$\square$ meadow & $\square$ coniferous forest \\
$\square$ mixed and deciuous forest & $\square$ other \\
$\square$ open water & \\
\hline
\end{tabular}

Fig. 6. Areal coverage of the different land-use types per recharge class for the conditions in 2000 .

Table 3. Groundwater budget ( $\mathrm{mm} /$ year).

\begin{tabular}{|c|c|c|c|c|c|c|}
\hline & & \multirow[t]{2}{*}{2000} & \multicolumn{4}{|c|}{2020} \\
\hline & & & A1 & $\mathrm{A} 2$ & B1 & B2 \\
\hline \multirow[t]{2}{*}{ In } & River leakage & 56 & 57 & 56 & 56 & 56 \\
\hline & Recharge & 313 & 304 & 308 & 307 & 310 \\
\hline \multirow[t]{5}{*}{ Out } & Wells & 34 & 34 & 34 & 34 & 34 \\
\hline & Drains & 103 & 101 & 102 & 102 & 102 \\
\hline & River leakage & 211 & 206 & 208 & 208 & 209 \\
\hline & Groundwater discharge & 20 & 20 & 20 & 20 & 20 \\
\hline & BASE FLOW & 314 & 307 & 310 & 309 & 312 \\
\hline
\end{tabular}

all scenarios; the highest decrease is again found for scenario $\mathrm{A} 1(2.2 \%)$. It is concluded that the total decrease in baseflow, caused by the changing land-use, is $2.3,1.3,1.5$ and $0.7 \%$ over the 20 years for scenario A1, A2, B1 and B2, respectively.

\subsection{Assessing uncertainties}

The scenarios incorporating the uncertainty regarding the future land-use demand are taken from the EURURALIS study. EURURALIS incorporates these uncertainties by adopting a multiple land-use scenario approach based on the world visions: A1 a global economic scenario, A2 a local economic scenario, B1 a global environmental scenario and B2 a local environmental scenario (Masui et al., 2001). As earlier mentioned the resulting land-use change scenarios are presented in Table 1.

ROC values obtained in this study (Table 4) show that the land-use model is capable of explaining relatively well the spatial variation of the land-use types urban, industry, coniferous forest, mixed forest, heather and wet meadow. Other land-use types as deciduous forest, agriculture and meadow are described less well by the used driving forces.

The $95 \%$ confidence bounds for the impact of the predicted land-use in 2020 on the groundwater levels, assuming SERS scenario A1 are shown in Fig. 12. The confidence bounds are in relation to the groundwater level changes due to scenario A1, provided in Fig 10a, and indicate that, in relation to the parameter uncertainty of the CLUE-S model, with 

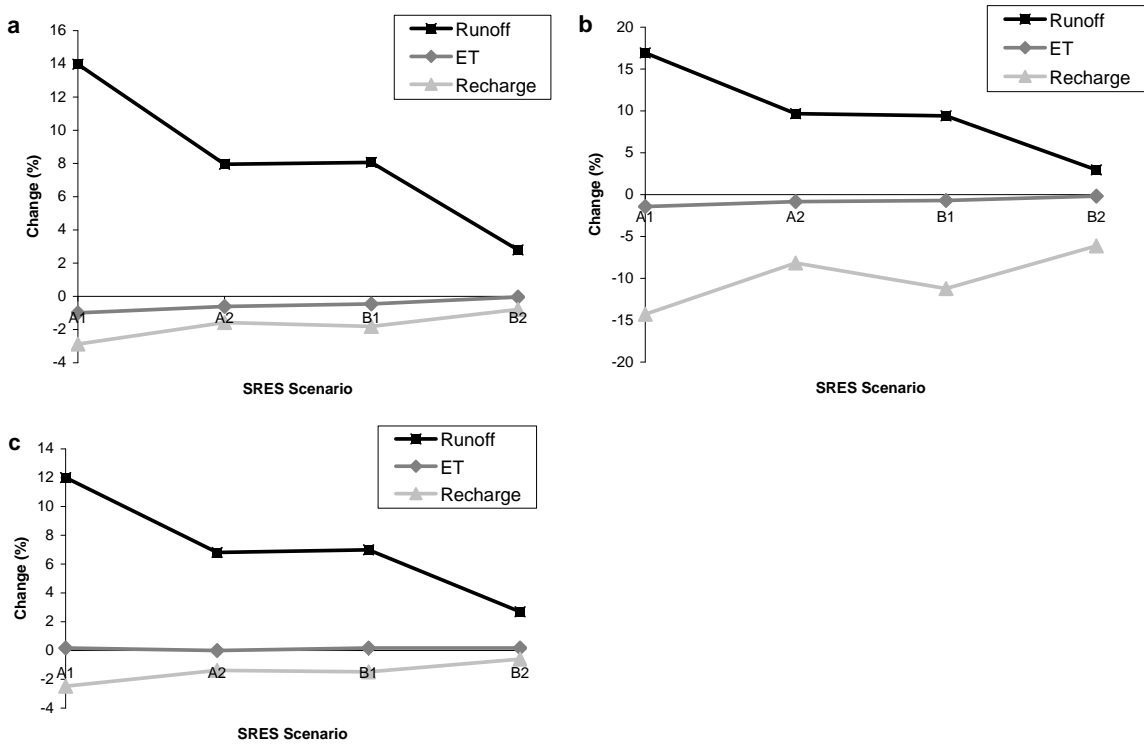

Fig. 7. Average change in surface runoff, evapotranspiration and recharge fluxes in 2020 compared to 2000 resulting from different land use scenarios: yearly change (a), changes in summer $(\mathbf{b})$, changes in winter $(\mathbf{c})$.
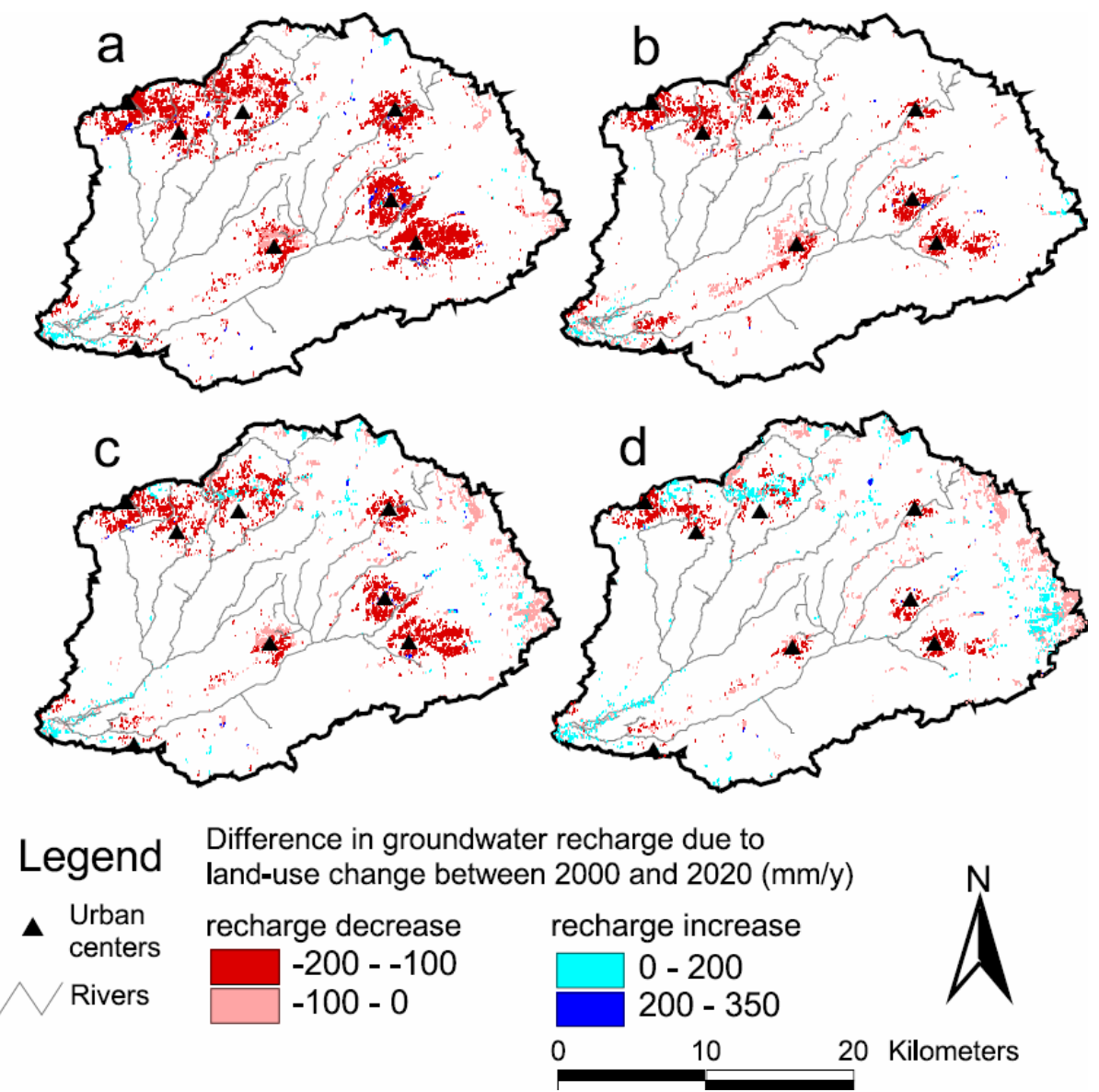

Fig. 8. Difference in groundwater recharge due to land-use change between 2000 and 2020 assuming SRES scenarios A1 in (a) A2 in (b), $\mathrm{B} 1$ in (c) and B2 in (d). 


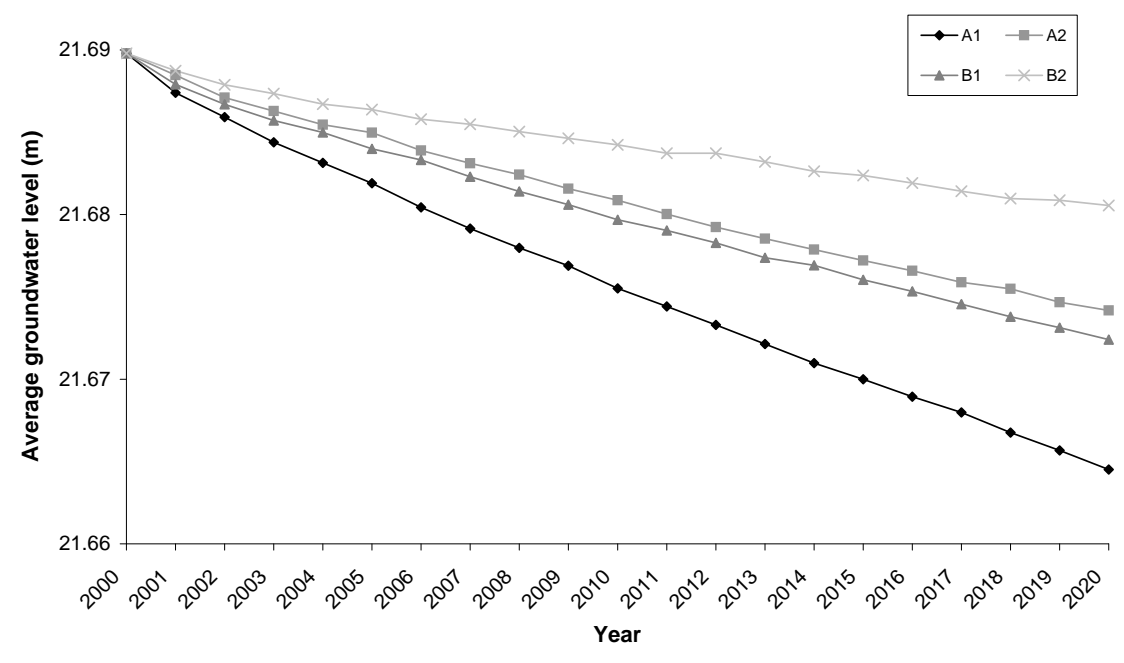

Fig. 9. Average change in groundwater level from 2000 till 2020 resulting from different land-use scenarios.
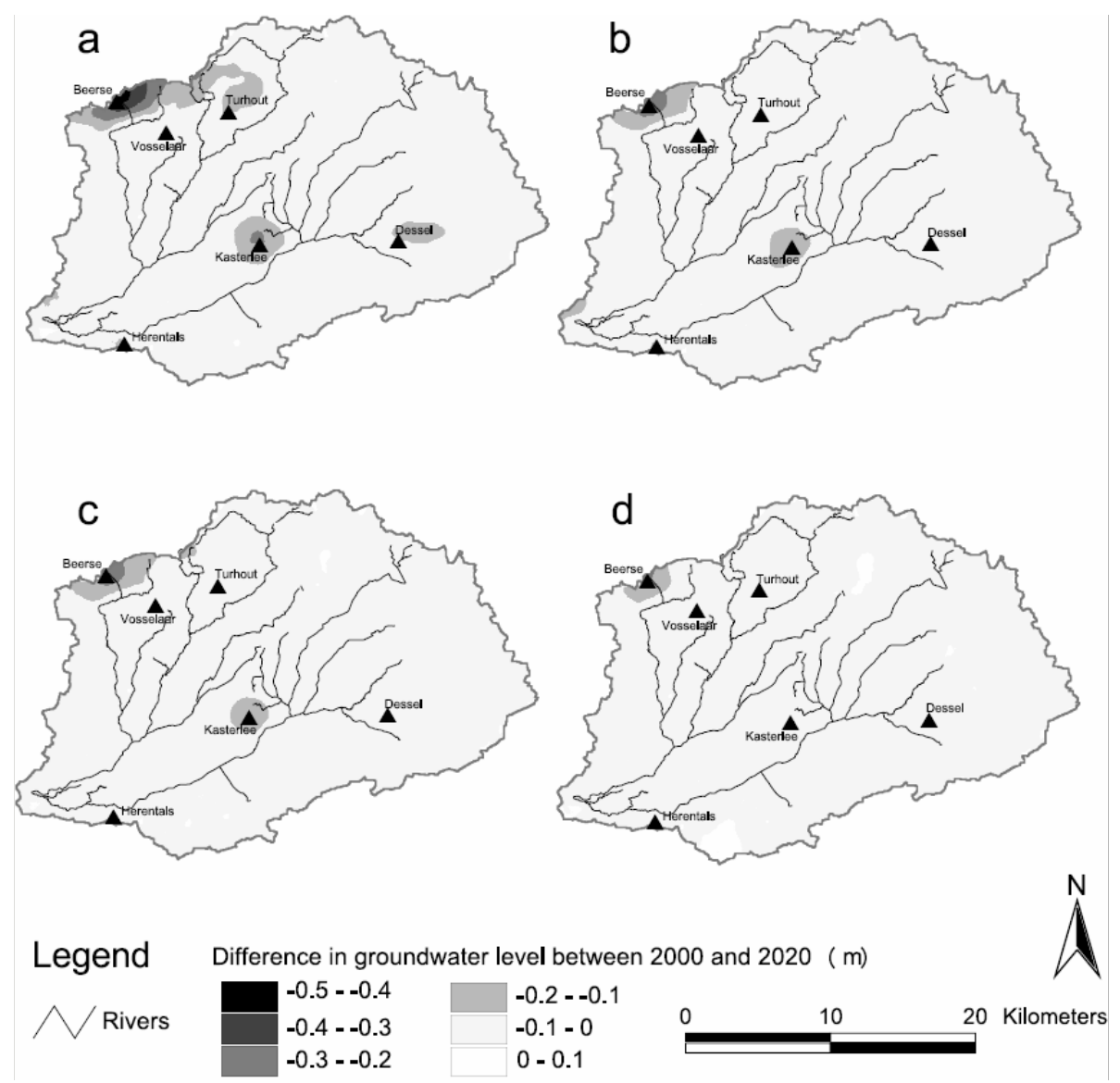

Fig. 10. Spatially distributed change in groundwater level assuming SRES scenario A1 (a), A2 (b), B1 (c) and B2 (d). 
Table 4. Relative Operating Characteristics of the logistic regression (-).

\begin{tabular}{cccccccccc}
\hline & Urban & Industry & Deciduous forest & Coniferious forest & Mixed forest & Agriculture & Heather & Meadow & Wet meadow \\
\hline ROC & 0.71 & 0.79 & 0.54 & 0.68 & 0.71 & 0.55 & 0.64 & 0.53 & 0.82 \\
\hline
\end{tabular}
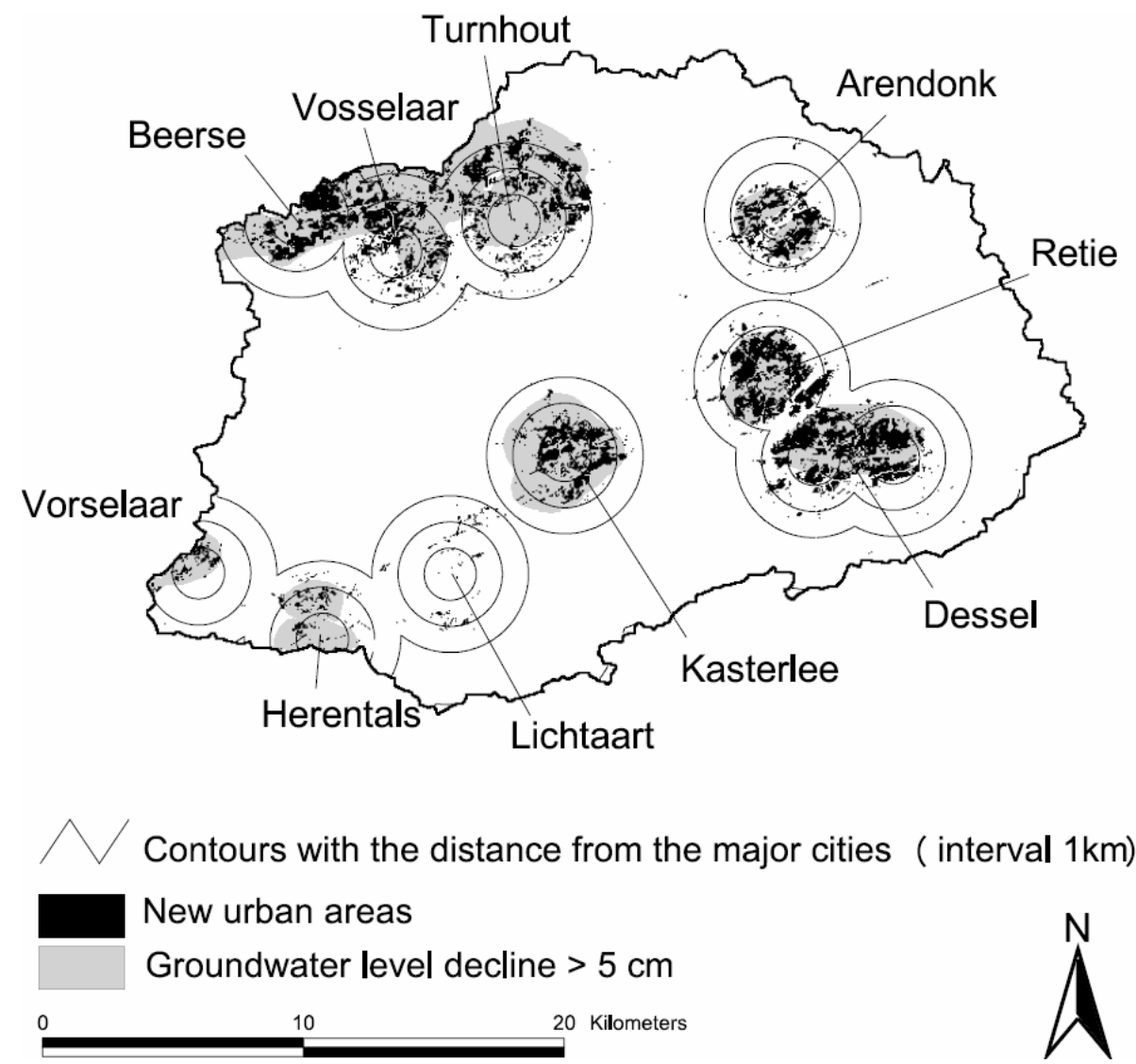

Fig. 11. Correspondence between groundwater level decrease between 2000 and 2020 (grey) and the increase in urban area (black) for SRES scenario A1. Contour lines indicate the distance to the present urban centers in the study area.

a probability of $95 \%$ the groundwater level change is in the range of the change indicated in Fig. 10a plus or minus the confidence bounds of Fig. 12. The confidence bound is less then $5 \mathrm{~mm}$ for most of the places in the catchment. At certain places in the basin as for example the regions: north of Vosselaar and Turnhout, south-west of Kasterlee, east of Vorselaar and south of Arendonk the uncertainty is slightly higher up to $30 \mathrm{~mm}$ and exceptionally up to $50 \mathrm{~mm}$. From these results it can be concluded that the uncertainty of the parameters can result in some changes related to the allocation of landuse change. Depending on the choice of parameters above mentioned regions become more or less attractive for urbanization. Also in the east of the basin there are some regions having somewhat higher confidence bounds, these are caused by a variation of the allocation of new forests.
The sensitivity of the WetSpass model towards land-use change is assessed using hypothetical scenarios. Fig. 13 shows the hypothetical effect on recharge if the present (year 2000) land-use is changed to a homogeneous land-use covering the entire basin. It is concluded, under current model settings, a $100 \%$ urbanized catchment would cause a decrease in total yearly recharge with $-24 \%$. On the other hand, a complete afforestation of the basin with deciduous forest would increase the yearly recharge with $+12 \%$. These changes in recharge show the general influence of land-use on recharge. However, the maximum or minimum recharge is likely to be obtained by a non-homogeneous spatial land-use distribution. 


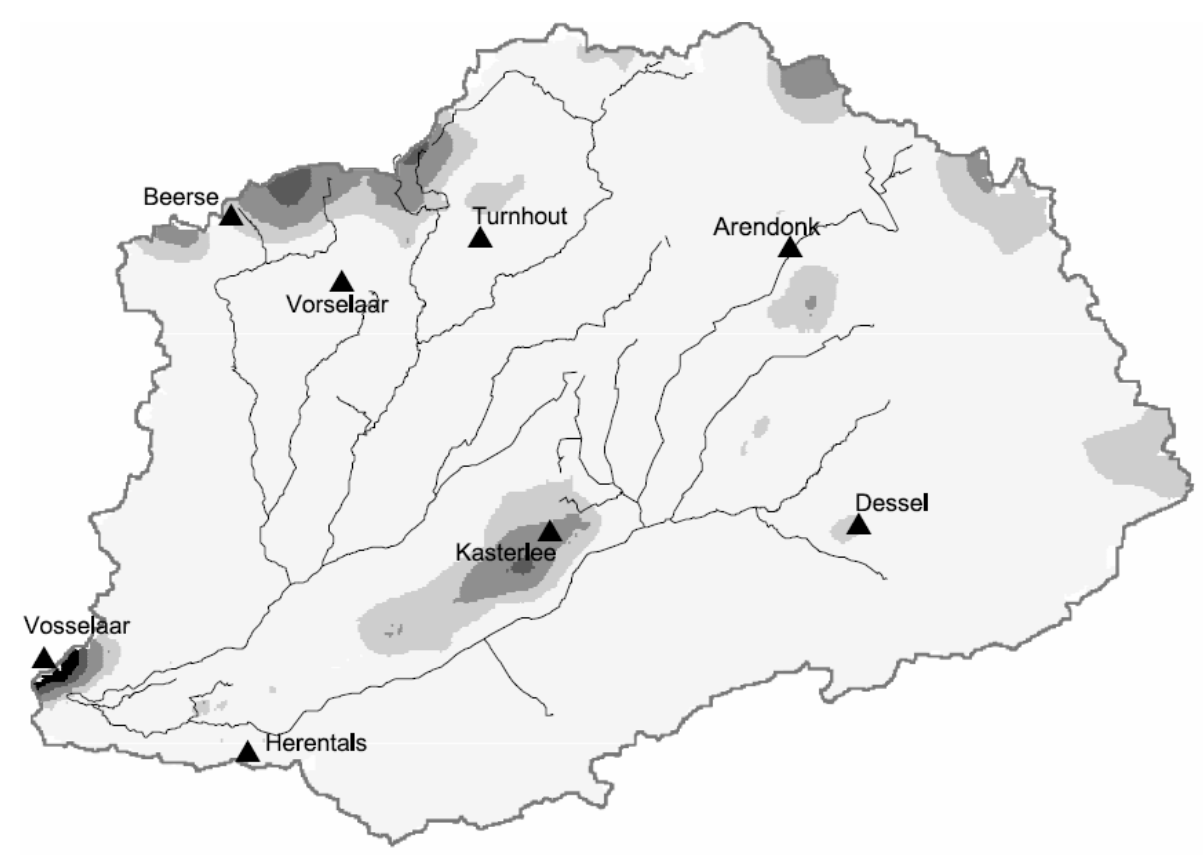

\section{Legend}

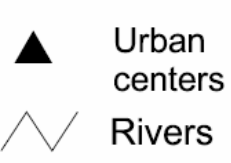

$95 \%$ Confidence bounds of the simulated groundwater level (2020) due to CLUE-S parameter uncertainty, assuming SRES scenario $A 1(\mathrm{~m})$

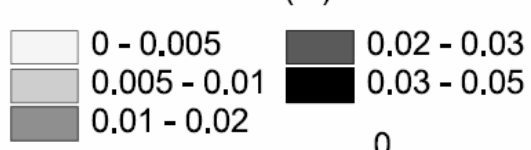

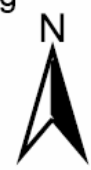

10 Kilometers

Fig. 12. 95\% Confidence bounds of the simulated groundwater level (2020) due to CLUE-S paramater uncertainty, assuming SRES scenario A1.

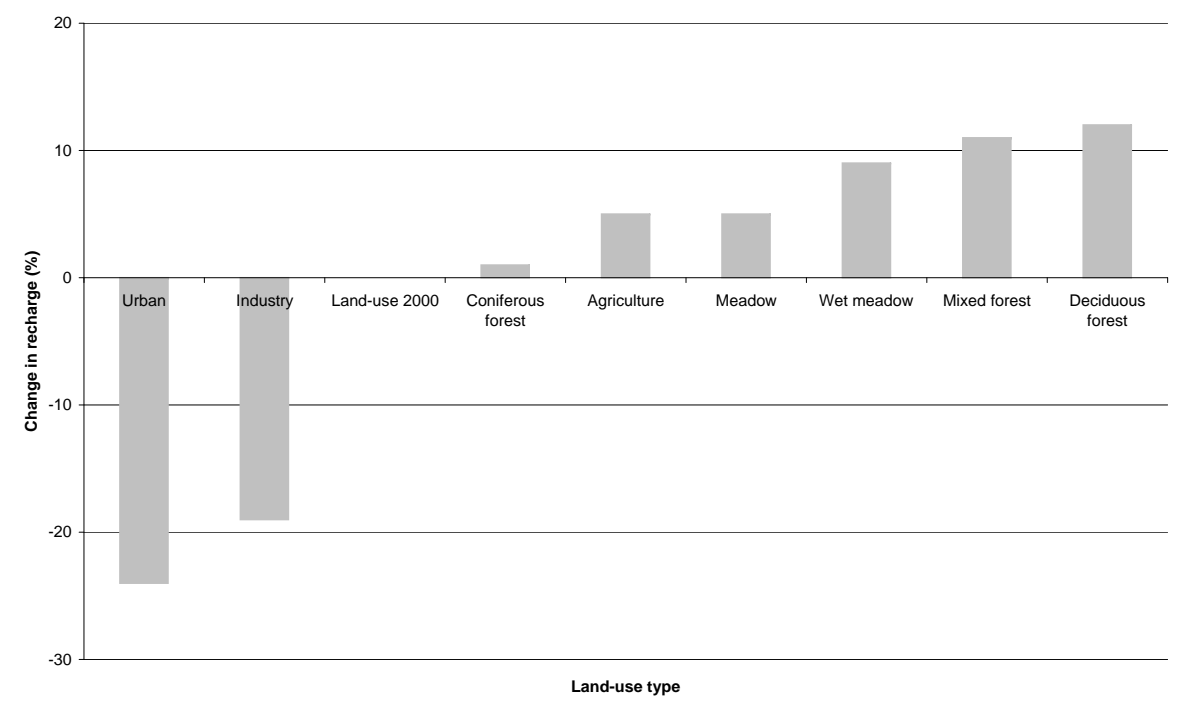

Fig. 13. Sensitivity to land-use of the yearly recharge simulated with WetSpass. Base situation is the present (2000) land-use and recharge condition, each bar shows the change in recharge if the land-use of the complete area is converted to the indicated land-use. 
The land-use type specific parameters in this paper are chosen constant over time. However, infiltration capacity in urbanized areas may change in the future due to new urban cover types. Furthermore, in this study only one class has been used for all agricultural crops, whereas different crops could have diverging hydrological properties, which may also depend on the agricultural management practices. The calibrated groundwater model, along with the WetSpass model, shows no systematic bias, a correlation coefficient of 0.99 , a mean absolute error of $0.41 \mathrm{~m}$, a root mean square error of $0.51 \mathrm{~m}$, and a Nash-Sutcliffe model efficiency of 0.99 between simulated and observed heads. The simulated groundwater heads for layers 1 and 2 versus the measured heads are presented in Fig. 14.

A yearly baseflow of $316 \mathrm{~mm}$ was obtained with WETSPRO. The calibration of the WetSpass and MODFLOW models resulted in a very similar baseflow value of $314 \mathrm{~mm}$. The water balance error resulting from the inflow and outflow calculated by MODFLOW is about $0.009 \%$ which is less than the $0.1 \%$ recommended by Konikow (1978).

\section{Conclusions}

This study simulates the effects of future land-use changes until the year 2020 on the yearly average groundwater levels and water balance components of the Kleine Nete-basin. Four land-use change scenarios (A1, A2, B1 and B2) based on the widely used world vision scenarios developed by the IPCC (Masui et al., 2001) are considered (Klijn et al., 2005). The land-use change CLUE-S, water balance WetSpass, and groundwater flow MODFLOW, models are coupled and applied in this study. The CLUE-S model is used for the spatial allocation of the land-use changes in the catchment. The distributed recharge is modelled with WetSpass, which has land-use as one of its inputs. The distributed recharge, on its turn, is used in a MODFLOW groundwater flow model of the Kleine Nete catchment to simulate head and baseflow changes. The compatibility of the WetSpass and MODFLOW models was shown by Batelaan et al. (2003) and Batelaan and De Smedt (2007). The novelty of this study is the successful coupling of a land-use change allocation model (CLUE-S) with a groundwater flow model, which allows estimating the range and spatial distribution of the effects of future land-use change on the groundwater system.

The results show that the predicted land-use changes from 2000 until 2020 will reduce the average groundwater head and flow slightly: the basin average groundwater level decreases with $2.5,1.6,1.7$ and $0.9 \mathrm{~cm}$, the baseflow decreases with $2.3,1.3,1.5$ and $0.7 \%$ for scenario A1, A2, B1 and B2, respectively. However, Fig. 8, 10 and 11 clearly show that the changes in recharge and groundwater level are concentrated within the vicinity of urban centres. The local maximum simulated groundwater level decrease is $45 \mathrm{~cm}$ for scenario A1. These results should be interpreted, taking into account

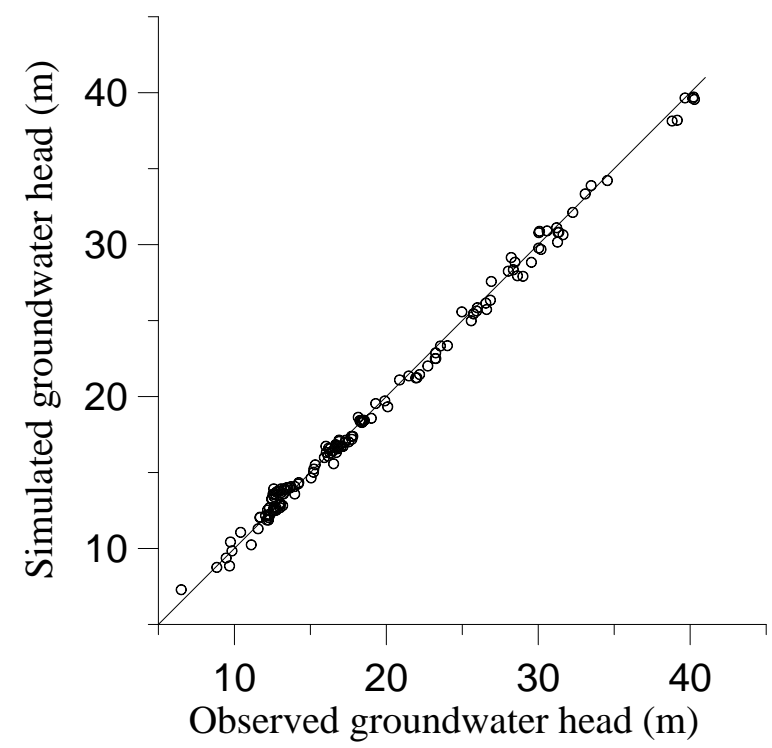

Fig. 14. Comparison of the simulated and observed groundwater head for the situation in 2000 .

the uncertainties addressed above, as indicative trends for future changes in the groundwater system. In addition, the results show a considerable difference between the response of the summer and winter recharge on the land-use changes. The seasonal groundwater level fluctuations are therefore expected to increase and consequently the stress on the groundwater resources will increase, especially in urbanized areas during summer.

In order to receive more inside knowledge on the impact of global changes on the groundwater system similar studies should be applied on different basins to incorporate the effect of the basins characteristics. In this study there is a considerable difference between winter and summer conditions, it would therefore be interesting to apply a similar methodology using transient water balance and groundwater models. In the future, the land-use modelling should be further improved including for example different agricultural crops and including the effect of alternative urban construction materials as permeable and semi-permeable pavements. Finally, the impact on land-use change should be combined with other global changes such as climate change to assess the future of our groundwater systems.

From this study, it is concluded that although, average changes in recharge, groundwater level and baseflow are not very large, near urban centres the effects of land-use changes on the groundwater system are considerable and deserve necessary pro-active planning for compensation of the negative effects.

Acknowledgements. The authors would like to thank the reviewers for their constructive comments which led to a considerable improvement of the paper. The first author acknowledges the support of the Research Council of the Vrije Universiteit Brussel 
and the Institute for the Promotion of Innovation by Science and Technology in Flanders. The research was further supported by the Belgian Science Policy Office in the framework of the MAMUD (SR/00/105) and FRAC-WECO (SD/TE/02) projects.

Edited by: A. Bronstert

\section{References}

Bahremand, A., De Smedt, F., Corluy J., Liu, Y. B., Poorova, J., Velcicka, L., and Kunikova, E.: WetSpa Model Application for Assessing Reforestation Impacts on Floods in Margecany-Hornad Watershed, Slovakia, Water Resour. Manag., 21(8), 1373-1391, 2006.

Batelaan, O. and De Smedt, F.: GIS-based recharge estimation by coupling surface-subsurface water balances, J. Hydrol, 337(3-4), 337-355, 2007.

Batelaan, O., De Smedt, F., and Triest, L.: Regional groundwater discharge: phreatophyte mapping, groundwater modelling and impact analysis of land-use change, J. Hydrol., 275(1-2), 86108, 2003.

Bhaduri, B., Harbor, J., Engel, B. A., and Grove, M.: Assessing watershed-scale, long-term hydrologic impacts of land use change using a GIS-NPS model, Environ. Manage., 26(6), 643$658,2000$.

Bosch, J. M. and Hewlett, J. D.: A review of catchment experiments to determine the effect of vegetation changes on water yield and evapotranspiration, J. Hydrol., 55(1-4), 3-23, 1982.

Bronstert, A., Niehoff, D., and Bürger, G.: Effects of climate and land-use change on storm runoff generation: present knowledge and modelling capabilities, Hydrol. Process. 16(2), 509-529, 2002.

Bronstert, A.: Rainfall-runoff modeling for assessing impacts of climate and land-use change, Hydrol. Process., 18, 567-570, 2004.

Brown, A. E., Zhang, L., McMahon, T. A., Western, A. W., and Vertessy, R. A.: A review of paired catchment studies for determining changes in water yield resulting from alterations in vegetation, J. Hydrol., 310, 28-61, 2005.

Bultot, F., Dupriez, G. L., and Gellens, D.: Simulation of land use changes and impacts on the water balance: a case study for Belgium, J. Hydrol., 114, 327-348, 1990.

Calder, I. R.: Hydrologic effects of land-use change, in: Handbook of hydrology, edited by: Maidment, D. R., McGraw-Hill, New York, USA, 13.1-13.50, 1993.

European Union: Directive 2006/118/EC of the European Parliament and of the Council of 12 December 2006, on the protection of groundwater against pollution and deterioration, Official Journal of the European Communities, 27 December 2006, L 372/19, 2006.

Fohrer, N., Haverkamp, S., Eckhardt, K., and Frede, H. G.: Hydrologic response to Land use changes on the catchment scale, Phy. Chem. Earth, 26(7-8), 577-582, 2001.

Gehrels, H., Peters, N. E., Hoehn, E., Jensen, K., Leibundgut, C., Griffioen, J., Webb, B., and Zaadnoordijk, W. J.: Impacts of human activity on groundwater dynamics, IAHS Publ., 269, 369 pp., 2001.

Harbaugh, A. W. and McDonald, M. G.: MODFLOW-2000, The U.S. Geological Survey modular groundwater model. User guide to modularization concepts and the groundwater flow process,
U.S. Geological Survey, Reston, Virginia, USA, Open File Rep. 00-92, 121 pp., 2000.

Hornbeck, J. W., Adams, M. B., Corbett, E. S., Verry, E. S., and Lynch, J. A.: Long-term impacts of forest treatments on water yield: a summary for northeastern USA, J. Hydrol., 150(2-4), 323-344, 1993.

Hundecha, Y. and Bárdossy, A.: Modeling of the effect of land use changes on the runoff generation of a river basin through parameter regionalization of a watershed model, J. Hydrol., 292, 281-295, 2004.

IPCC: Climate Change 2007: The Physical Science Basis. Contribution of Working Group I to the Fourth Assessment Report of the Intergovernmental Panel on Climate Change, edited by: Solomon, S., Qin, D., Manning, M., Chen, Z., Marquis, M., Averyt, K. B., Tignor, M., and Miller, H. L., Cambridge University Press, Cambridge, UK and New York, NY, USA, 996 pp., 2007.

Klijn, J. A., Vullings, L. A. E., v.d. Berg, M., van Meijl, H., van Lammeren, R., van Rheenen, T., Tabeau, A. A., Veldkamp, A., Verburg, P. H., Westhoek, H., and Eickhout, B., The EURURALIS study: Technical document, Wageningen, The Netherlands, Alterra, Alterra-rapport 1196, 215 pp., 2005.

Klöcking, B. and Haberlandt, U.: Impact of land use changes on water dynamics - a case study in temperate meso and macroscale river basins, Phys. Chem. Earth, 27, 619-629, 2002.

Konikow, L. F.: Calibration of ground-water models, In: Verification of mathematical and physical models in hydraulic engineering, American Society of Civil Engineers, NY, USA, 87-93, 1978.

Lin, Y. P., Hong, N. M., Wu P. J, et al.: Modeling and assessing landuse and hydrological processes to future land-use and climate change scenarios in watershed land-use planning, Environ. Geol., 52(3), 623-634, 2007.

Masui, T., Matsuoka, Y., Morita, T., Kainuma, M., and Takahashi, K.: Development of Land Use Model for IPCC New Emission Scenarios (SRES), in: Present and Future of Modeling Global Environmental Change, Toward Integrated Modeling, Matsuno, T. and Kida, H., ISBN 4-88704-127-6, Terra Scientific Publishing Company, Tokyo, Japan, 441-448, 2001.

McColl C. and Aggett, G.: Land-use forecasting and hydrologic model integration for improved land-use decision support, J. Environ. Manage., 84, 494-512, 2007.

Meyus, Y., Adyns, D., Severyns, J., Batelaan, O., and De Smedt, F.: Development of regional models in requirement of the Flemish Groundwater Model in GMS/MODFLOW. Parcel 1: The central Campine model (in Dutch), in: Report part 1: Basic data and conceptual model (in Dutch), Ministry of the Flemish government, Departement Leefmilieu en Infrastructuur, Administratie Milieu, Natuur, Land- en Waterbeheer, Afdeling Water (currently Vlaamse Milieu Maatschappij, Afdeling Water), 131 pp., 2004.

Niehoff, D., Fritsch, U., and Bronstert, A.: Land-use impacts on storm-runoff generation: scenarios of land-use change and simulation of hydrological response in a meso-scale catchment in SW-Germany, J. Hydrol., 267, 80-93, 2002.

OC GIS-Vlaanderen: Digital version of Land-cover data set of Flanders 2001, Agentschap voor Geografische Informatie Vlaanderen, Ghent, Belgium, on CD-ROM, 2001.

Ott, B. and Uhlenbrook, S.: Quantifying the impact of land-use changes at the event and seasonal time scale a process-oriented catchment model, Hydrol. Earth Syst. Sci., 8, 62-78, 2004, 
http://www.hydrol-earth-syst-sci.net/8/62/2004/.

Overmars, K. and Verburg P. H.: Analysis of land use drivers at the watershed and household level: linking two paradigms at the Philippine forest fringe, Int. J. Geograph. Inform. Sci., 19, 125152, 2005.

Robinson, M., Cognard-Plancq, A. L., Cosandey, C., David, J., Durand, P., Fuhrer, H. W., Hall, R., Hendriques, M. O., Marc, V., McCarthy, R., McDonnell, M., Martin, C., Nisbet, T., O'Dea, T. P., Rodgers, M., and Zollner, A.: Studies of the impact of forests on peak flows and base flows: A European perspective, Forest Ecology, 186, 85-97, 2003.

Tang, Z., Engel, B. A., Pijanowski, B. C., and Lim, K. J.: Forecasting land use change and its environmental impact at a watershed scale, J. Environ. Manage., 76, 35-45, 2005.

Tong, S. T. Y. and Liu, A. J.: Modelling the hydrologic effects of land-use and climate changes, Int J. Risk Assess. Manag., 6(45), 344-368, 2006.

UN/WWAP (United Nations/World Water Assessment Programme), UN World Water Development Report 2: Water a shared responsibility. United Nations Educational, Scientific and Cultural Organization, Paris, France and Berghahn Books, New York, USA, 600 pp., 2006.

US EPA: Projecting Land-use change: summary of models for assessing the effects of community growth models and change of land use patterns, United States Environmental Protection Agency, Washington, USA, EPA/600/R-00/098, September 2000.

Vázquez-Suñé, E., Sanchez-Vila, X., and Carrera, J.: Introductory review of specific factors influencing urban groundwater, an emerging branch of hydrogeology, with reference to Barcelona, Spain, Hydrogeol. J., 13(3), 522-533, 2005.

Verbeiren, B., Batelaan, O., and De Smedt, F.: Development of Regional Models for the Flanders Groundwater Model in GMS/MODFLOW. Part 1: Central Campine System. (In Dutch), in: Report part 2: Building up the groundwater model, sensitivity analysis and calibration (in Dutch), Ministry of the Flemish government, Departement Leefmilieu en Infrastructuur, Administratie Milieu, Natuur, Land- en Waterbeheer, Afdeling Water (currently Vlaamse Milieu Maatschappij, Afdeling Water), 60 pp., 2006.
Verburg, P. H., Mastura, S. S. A., Soepboer, W., Veldkamp, A., Limpiada, R., and Espaldon, V.: Modelling the spatial dynamics of regional land use: the CLUE-S Model, Environ. Manage., 30(3), 391-405, 1999.

Verburg, P. H., Veldkamp, T., Overmars, K., Lesschen, J. P., and Kok, K.: Manual for the CLUE-S model, Wageningen University, The Netherlands, $47 \mathrm{pp}$., online available at: http://www. cluemodel.nl, 2004.

Walker, W. E., Harremoës, P., Rotmans, J., van der Sluijs, J. P., van Asselt, M. B. A., Janssen, P., and Krayer von Krauss, M. P.: Defining uncertainty: a conceptual basis for uncertainty management in model-based decision support. Integrated Assessment, 4, 5-18, 2003.

Wang, S., Kang, S., Zhang, L., and Li, F.: Modelling hydrological response to different land-use and climate change scenarios in the Zamu River basin of northwest China, Hydrol. Process., 22(14), 2502-2510, doi:10.1002/hyp.6846, 2008.

Willems, P.: WETSPRO: Water Engineering Time Series PROgramming tool, Methodology and User's Manual, Version 2.0. Katholieke Universiteit Leuven, Belgium, 2003.

Woldeamlak, S. T., Batelaan O. and De Smedt F.: Effects of climate change on the groundwater system in the Grote-Nete catchment, Belgium, Hydrogeol. J., 15, 891-901, doi:10.1007/s10040-0060145-x, 2007.

Wouters, L. and Vandenberghe, N.: Geology of the Kempen: a synthesis (in Dutch), Nationale instelling voor radio-actief afval en verrijkte splijtstoffen (NIRAS) 94-11, Brussels, Belgium, 208 pp., 1994. 